\title{
A LIVER ENZYME THAT CONJUGATES SULFOBROMOPHTHALEIN SODIUM WITH GLUTATHIONE *
}

\author{
By BURTON COMBES † AND GENEVA SUE STAKELUM
}

\author{
(From the Department of Internal Medicine, The University of Texas Southwestern Medical \\ School, Dallas, Texas)
}

(Submitted for publication December 2, 1960; accepted February 10, 1961)

In the past few years, considerable evidence has been presented indicating that sulfobromophthalein sodium (BSP) is metabolized in the liver $(1-6)$. Recently, we have demonstrated that the major pathway of BSP metabolism in man and in the rat involves conjugation of BSP with. the tripeptide glutathione (5). Similar results have been obtained by Javitt and his associates in the dog (6). Grodsky, Carbone and Fanska concluded "that BSP is excreted at least in part as a mercaptide with cysteine or the peptide glutathione," in man (4). These latter authors are not certain about the presence of glutathione, however, since they feel that glycine and glutamic acid are possible contaminants of the BSP metabolites.

The results of the present investigation disclosed three critical features of hepatic BSP metabolism; first, an enzyme is described, identified in liver, which catalyzes the conjugation of BSP and glutathione; second, glutathione is shown to be the preferred substrate for the enzyme; finally, it is demonstrated that 1 mole of bromide ion is released from BSP for each mole of BSP-glutathione formed.

\section{METHODS}

1. Preparation of liver homogenates and subcellular fractions. Adult, male, Sprague-Dawley rats were stunned by a blow on the head, their throats cut, and their livers perfused through the portal vein with $20 \mathrm{ml}$ of ice-cold phosphate buffer, $0.1 \mathrm{M}, \mathrm{pH}$ 7.8. The livers were then excised and placed in cold buffer to cool. After weighing, the livers were homogenized in a Dounce homogenizer (7) with a volume of phosphate buffer equal to the weight of the liver. The resulting homogenate

* This work was supported by research grants from the United States Public Health Service [H-3439], and the American Heart Association. Part of this work has appeared in abstract form ( J. clin. Invest. 1960, 39, 978) and was presented at the annual meeting of the American Association for the Study of Liver Diseases, Chicago, Ill., November, 1960.

$\dagger$ Established Investigator of the American Heart Association. was centrifuged at $800 \mathrm{G}$ for 10 minutes at $-1^{\circ} \mathrm{C}$ The supernatant containing the broken liver cells minus nuclei and strands of connective tissue was called homogenate and was used as follows. For preparation of subcellular fractions, mitochondria were spun at $12,800 \mathrm{G}$ for 10 minutes at $-1^{\circ} \mathrm{C}$ in a Servall refrigerated centrifuge. Microsomes were then separated from the resulting supernatant by centrifuging at $144,000 \mathrm{G}$ for 30 minutes at $0^{\circ} \mathrm{C}$ in a Spinco model $\mathrm{L}$ ultracentrifuge. The mitochondria and microsomes were washed once in ice-cold phosphate buffer, recentrifuged at $12,800 \mathrm{G}$ for 10 minutes, and at $144,000 \mathrm{G}$ for 30 minutes, respectively, and after discarding the wash, were resuspended in a volume of phosphate buffer equivalent to the volume of the homogenate from which they were obtained. The fraction remaining after removal of microsomes was called the supernatant. A portion of the original homogenate was boiled for 5 minutes at $100^{\circ} \mathrm{C}$. It was then centrifuged at $144,000 \mathrm{G}$ for 30 minutes. The resulting supernatant was removed and labeled KS fraction.

2. Incubation procedure. Homogenate and subcellular fractions were incubated in test tubes with BSP and other substrates at $37^{\circ} \mathrm{C}$ in a constant temperature water bath. The incubation volume varied from 1 to $3 \mathrm{ml}$ (see figures and tables for details of different experiments). Incubation was terminated by addition of $0.36 \mathrm{ml}$ saturated ammonium sulfate and $5 \mathrm{ml}$ of absolute ethanol. After thorough mixing and standing for 20 minutes at room temperature, the tubes were centrifuged at $2,500 \mathrm{rpm}$ for 10 minutes. On the average, 92.5 and 97.0 per cent of added BSP were recovered in the supernatants from tubes containing homogenate and subcellular fractions, respectively.

3. Chromatography and electrophoresis of BSP compounds. Descending chromatograms of the above supernatants were made on Whatman no. 1 filter-paper strips. BSP bands were identified by exposing the dried papers to ammonia vapors. The bands were eluted into $0.1 \mathrm{~N}$ $\mathrm{KOH}$ and the concentration of BSP in the eluate determined in a Beckman DU spectrophotometer set at 575 $\mathrm{m} \mu$. The chromatographic techniques and the methods of quantitating BSP on chromatograms have been described in detail in a previous publication (5). Electrophoresis of BSP compounds was carried out in a Spinco model $\mathrm{R}$ paper electrophoretic apparatus at $500 \mathrm{v}$ for 3 hours, using $5 \mathrm{~N}$ acetic acid, $\mathrm{pH} 1.9$, as the conducting solution. Inorganic bromide was detected in incubation mixtures by paper chromatography, using 80 per cent acetone as the solvent (8). The bromide spots 


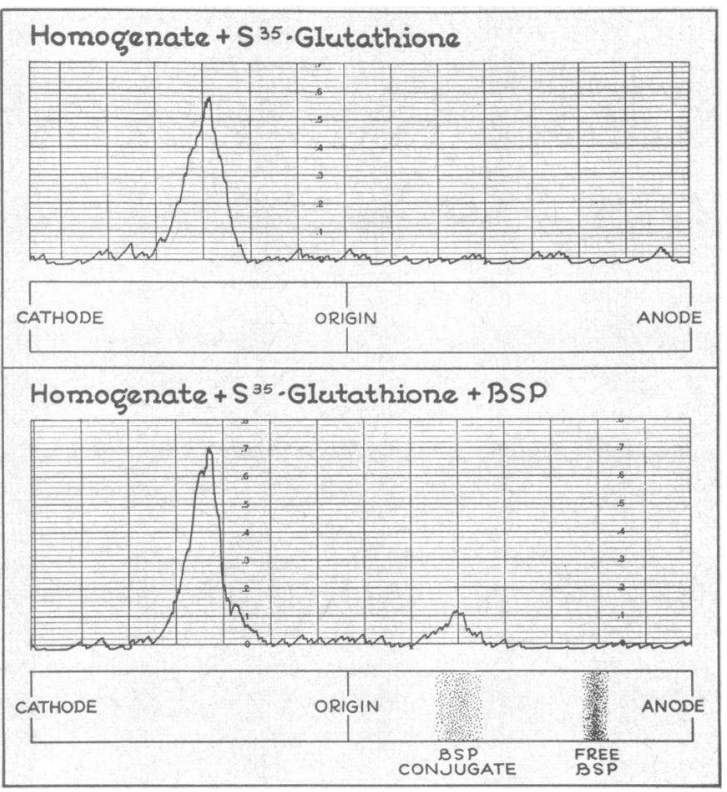

Fig. 1. InCORPORATION OF $\mathrm{S}^{35}$-LABELED GLUTATHIONE INTO BSP CONJUGATE SYNTHESIZED BY LIVER HOMOGENATE in vitro. See text for details.

were developed by the technique of Mitchell (9). The concentration of bromide in bands from unknown solutions was quantitated visually, by comparison with the size and intensity of staining of bands of known $\mathrm{NaBr}$ standards applied on the same chromatogram. By applying varying aliquots of unknown solutions and several standards, it was possible to quantitate the bromide content with an accuracy of approximately \pm 25 per cent.

4. Materials. Glutathione, $\mathrm{S}^{35}$-labeled glutathione, oxidized glutathione and cysteine were purchased from Schwarz Laboratories. Cysteinyl glycine was purchased from Mann Research Laboratories. BSP and phenoltetrabromphthalein were obtained from Hynson, Westcott and Dunning. ${ }^{1}$

\section{RESULTS}

Incubation of BSP with a rat liver homogenate yielded two distinct BSP bands. One traveled with an Rf of 0.71 and chromatographically and electrophoretically was identical with free BSP. The other, with an $\mathrm{Rf}$ of 0.41 , was chromatographically and electrophoretically identical with the major $\mathrm{BSP}$ conjugate found in rat bile, BSP-A, which in previous studies (5) was shown to be a conjugate of BSP and glutathione. Although identical chromatographic and electrophoretic mobilities suggest ' he same chemical structure, additional studies were carried out to determine the biochemical nature of

\footnotetext{
$1 \mathrm{We}$ are indebted to H. A. Brown Dunning, Jr., for a generous supply of phenoltetrabromphthalein.
}

the BSP compound formed in vitro. These revealed that the compound synthesized in vitro is the same as the major BSP compound formed in vivo. Conjugate was eluted from paper chromatograms and passed through a Dowex-50X, 200 to 400 mesh, ion exchange column (2) to remove any free amino acids or small peptides migrating with the same $\mathrm{Rf}$ as the BSP conjugate. The compound was then hydrolyzed with $5.9 \mathrm{~N} \mathrm{HCl}$ in a sealed tube at $100^{\circ} \mathrm{C}$ for 18 hours. Two-dimensional amino acid chromatograms of the hydrolysate $(10,11)$ revealed glycine and glutamic acid in equimolar quantities, and relatively smaller amounts of alanine. In previous studies in which $\mathrm{BSP}$ conjugates were hydrolyzed in $\mathrm{HCl}$, alanine was shown to represent cysteine minus its sulfhydryl group (5). The amino acids identified by paper chromatography are those contained in the tripeptide glutathione.

$S^{35}$-labeled reduced glutathione was incubated with a mixture of liver homogenate and BSP. After precipitation with ammonium sulfate and absolute ethanol, an aliquot of the supernatant was placed on paper and subjected to electrophoresis. BSP compounds were identified and the paper was then scanned for radioactivity ${ }^{2}$ (Fig-

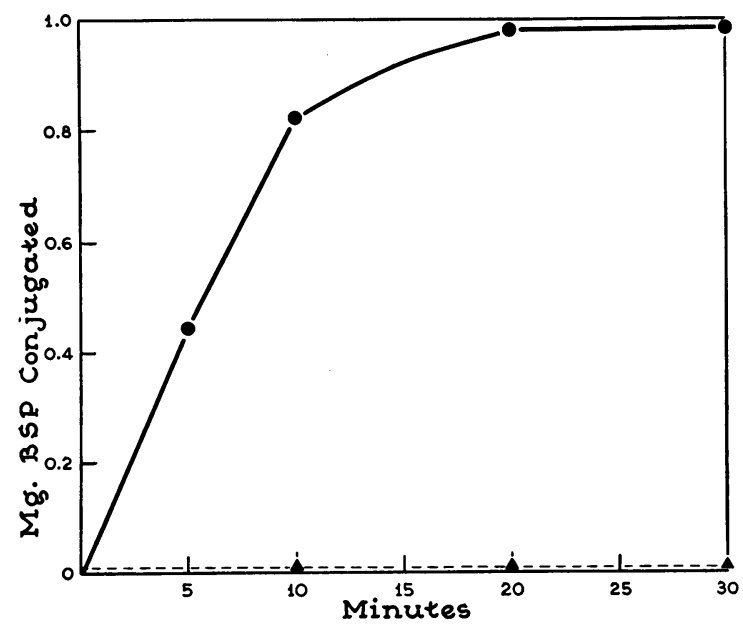

Fig. 2. Formation of BSP conjugate by rat liver HOMOGENATE. One $\mathrm{ml}$ of rat liver homogenate was incubated with $2 \mathrm{mg} \mathrm{BSP}$ at $37^{\circ} \mathrm{C}$ for varying times. Approximately $1 \mathrm{mg}$ of $\mathrm{BSP}$ was conjugated by $20 \mathrm{~min}$ utes (- ). Preheating liver homogenate at $100^{\circ}$ $\mathrm{C}$ for 5 minutes destroyed its capacity to catalyze conjugate formation $(\boldsymbol{\Delta}----\boldsymbol{\Delta})$.

2 Model RSC-SA chromatogram scanner manufactured by Atomic Accessories, Inc. 


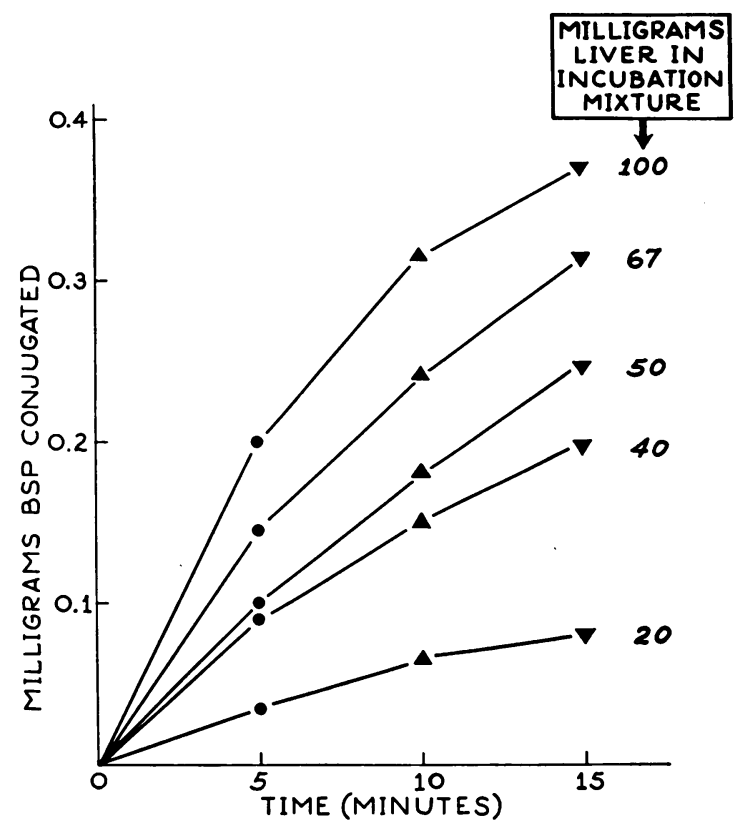

Fig. 3. BSP CONJUGate Formation With VARYing AMOUNTS OF LIVER. Rat liver homogenate ( $500 \mathrm{mg}$ liver, wet weight, per $\mathrm{ml} 0.1 \mathrm{M}$ phosphate buffer, $\mathrm{pH} 7.8$ ) was diluted with phosphate buffer to yield varying concentrations. Incubation mixture consisted of $1 \mathrm{ml}$ diluted liver homogenate, $0.75 \mathrm{mg} \mathrm{BSP}$ in $0.2 \mathrm{ml}$ phosphate buffer, and $4 \mathrm{mg}$ glutathione in $0.1 \mathrm{ml}$ phosphate buffer. Incubation was carried out in a constant temperature water bath set at $37^{\circ} \mathrm{C}$. At varying time intervals, the reaction was stopped by addition of $0.36 \mathrm{ml}$ saturated $\left(\mathrm{NH}_{4}\right)_{2} \mathrm{SO}_{4}$ and $5 \mathrm{ml}$ absolute ethanol. Quantitation of BSP conjugate formation was carried out as described in Methods. A zero time reagent blank for each concentration of liver homogenate was set up as follows. One $\mathrm{ml}$ of liver homogenate was mixed with $4 \mathrm{mg}$ glutathione in $0.1 \mathrm{ml}$ phosphate buffer. The mixture was precipitated, as described above, by $\left(\mathrm{NH}_{4}\right)_{2} \mathrm{SO}_{4}$ and absolute ethanol. BSP, $0.75 \mathrm{mg}$ in $0.2 \mathrm{ml}$ phosphate buffer, was then added to the precipitated contents of the tube. The optical density of the eluted paper chromatographic area of the reagent blank, corresponding to the BSP conjugate area, was subtracted from the optical density of the eluted BSP conjugate to yield a net optical density due to BSP conjugate. At each time interval, larger amounts of BSP were conjugated with increasing amounts of liver in the incubation mixture.

ure 1). A peak of radioactivity conforming to glutathione and migrating toward the cathode was observed on the control paper prepared from a mixture of homogenate and $\mathrm{S}^{35}$-labeled glutathione. In the homogenate mixture incubated with BSP, two BSP bands, identified as BSP conjugate and free BSP, had migrated toward the anode. The peak of radioactivity due to free glutathione was present on the cathode side, as in the control. Radioactivity was associated with the BSP band corresponding to BSP conjugate, indicating that radioactive glutathione was incorporated into this BSP compound.

The quantity of BSP conjugated during a 30 minute period in one experiment is shown in Figure 2. When the homogenate was heated for 5 minutes at $100^{\circ} \mathrm{C}$, prior to incubation with $\mathrm{BSP}$, its capacity to form the BSP conjugate was destroyed, suggesting that conjugate formation was catalyzed by an enzyme in liver. To strengthen this impression, varying amounts of liver homogenate made up to constant volume in $0.1 \mathrm{M}$ phosphate buffer, $\mathrm{pH} 7.8$, were incubated with quantities of BSP and glutathione shown to yield maximal amounts of conjugate formation. The system used is described in the legend of Figure 3. The rate of conjugate formation increased when increasing amounts of liver were added to the incubation mixture (Figures 3 and 4 ). The absolute quantity of BSP conjugated in each of three successive 5-minute intervals was greatest in the

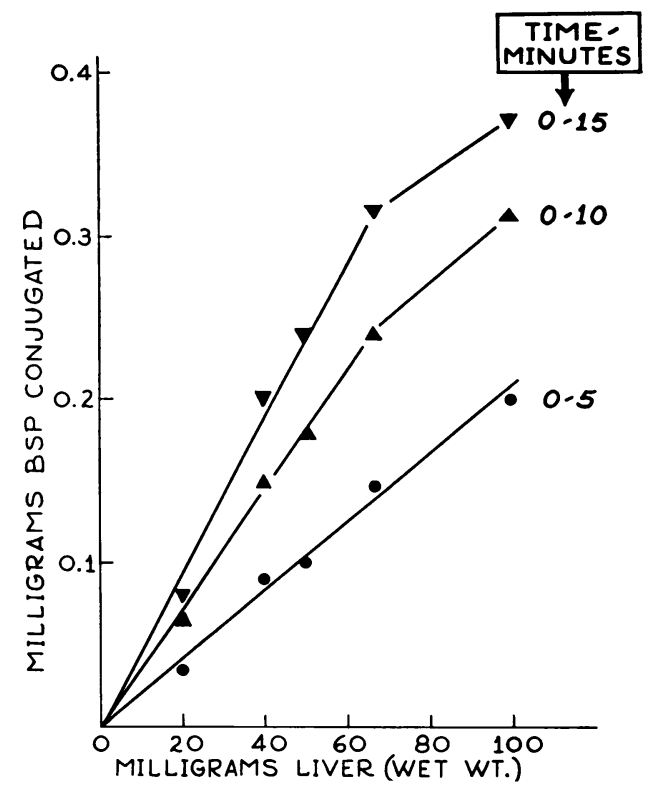

Fig. 4. Rate of BSP conjugate formation as FuncTION OF QUANTITY OF LIVER IN INCUBATION MIXTURE. Data of Figure 3 were replotted. The total quantity of $\mathrm{BSP}$ conjugated in the intervals 0 to 5,0 to 10 , and 0 to 15 minutes was plotted against the amount of liver in incubation mixture. The rate of conjugate formation was proportional to the quantity of liver present, except for the 0 to 10 and 0 to 15 minute values of the mixture containing $100 \mathrm{mg}$ of liver. See text for details. 
TABLE I

Incubation of BSP with homogenate and subcellular fractions of rat liver *

\begin{tabular}{|c|c|c|c|c|c|c|c|c|c|c|c|}
\hline & Homogenate & $\begin{array}{l}\text { Iomogenate } \\
\text { heated at } \\
100^{\circ} \mathrm{C} \text { for } \\
5 \mathrm{~min}\end{array}$ & $\begin{array}{l}\text { Super- } \\
\text { natant }\end{array}$ & $\begin{array}{l}\text { Mito- } \\
\text { chondria }\end{array}$ & $\begin{array}{l}\text { Micro- } \\
\text { somes }\end{array}$ & $\begin{array}{c}\text { Mito- } \\
\text { chondria } \\
+ \\
\mathrm{KS}\end{array}$ & $\begin{array}{c}\text { Micro- } \\
\text { somes } \\
+ \\
\mathrm{KS}\end{array}$ & $\begin{array}{c}\text { Super- } \\
\text { natant } \\
+ \\
\text { mito- } \\
\text { chondria }\end{array}$ & $\begin{array}{c}\text { Super- } \\
\text { natant } \\
+ \\
\text { micro- } \\
\text { somes }\end{array}$ & $\begin{array}{c}\text { Micro- } \\
\text { somes } \\
+ \\
\text { mito- } \\
\text { chondria }\end{array}$ & $\begin{array}{c}\text { Micro- } \\
\text { somes } \\
+ \\
\text { mito- } \\
\text { chondria } \\
+ \\
\mathrm{KS}\end{array}$ \\
\hline \multicolumn{12}{|l|}{ BSP conjugate } \\
\hline Rf & 0.41 & & 0.45 & & & & & 0.42 & 0.42 & & \\
\hline $\begin{array}{c}\text { Quantity BSP } \\
\text { conjugated } \\
\text { mg } / 5 \mathrm{~min}\end{array}$ & 0.448 & 0 & 0.452 & $\mathbf{0}$ & $\mathbf{0}$ & $\mathbf{0}$ & $\mathbf{0}$ & 0.466 & 0.410 & $\mathbf{0}$ & $\mathbf{0}$ \\
\hline \multicolumn{12}{|l|}{ Free BSP } \\
\hline Rf & 0.71 & 0.72 & 0.71 & 0.73 & 0.72 & 0.72 & 0.70 & 0.72 & 0.71 & 0.74 & 0.72 \\
\hline
\end{tabular}

* Incubation mixture contained $1 \mathrm{ml}$ of each specified fraction with final volume brought to $3 \mathrm{ml}$ by addition of $0.1 \mathrm{M}$ phosphate buffer, pH 7.8. Each tube was warmed in a $37^{\circ} \mathrm{C}$ water bath for 5 minutes. Then, $2 \mathrm{mg}$ of BSP was added to each tube and incubation continued for 5 minutes, after which it was terminated as described in Methods.

first 5-minute period and least in the last. Nevertheless, at each time interval, the amount of conjugate formed was proportional to the quantity of liver present, and thus presumably to enzyme concentration. Deviation from proportionality was observed only in periods 0 to 10 minutes and 0 to 15 minutes, with the incubation mixture containing the largest quantity of liver, namely $100 \mathrm{mg}$. This deviation would seem to be explained best by a lack of sufficient substrate in the incubation mixture to saturate fully the enzyme contained in 100 $\mathrm{mg}$ of liver after 5 minutes of incubation.

In order to localize the site of enzyme activity within the cell, BSP was incubated with various subcellular fractions of liver. BSP conjugate was formed only in those tubes containing the super- natant fraction of liver (Table I). Furthermore, all of the conjugating activity of the liver homogenate was accounted for in the supernatant fraction. No conjugate was formed with mitochondria, microsomes, or mixture of these, even with the addition of $\mathrm{KS}$ fraction. Addition of mitochondria or microsomes to the supernatant did not enhance its conjugating activity.

Supernatant fraction of liver which had been dialyzed against phosphate buffer for 24 hours at $0^{\circ} \mathrm{C}$ did not form conjugate when incubated with BSP. Conjugating activity was restored, however, upon the addition of KS fraction. Furthermore, BSP conjugate was also synthesized when glutathione alone was added to dialyzed supernatant. No additional cofactor was required.

TABLE II

Quantity of BSP conjugated with glutathione, cysteinyl glycine and cysteine*

\begin{tabular}{|c|c|c|c|c|c|}
\hline \multirow[b]{2}{*}{ Species } & \multirow[b]{2}{*}{$\begin{array}{l}\text { Quantity of } \\
\text { liver in } \\
1 \mathrm{ml}\end{array}$} & \multicolumn{4}{|c|}{ BSP conjugated in 15 minutes with: } \\
\hline & & $\begin{array}{l}\text { No peptide } \\
\text { or amino } \\
\text { acid added }\end{array}$ & $\begin{array}{l}\text { Glutathione } \\
(4 \mathrm{mg})\end{array}$ & $\begin{array}{l}\text { Cysteinyl } \\
\text { glycine } \\
(2.3 \mathrm{mg})\end{array}$ & $\begin{array}{l}\text { Cysteine } \\
(1.6 \mathrm{mg})\end{array}$ \\
\hline & $m g$ & \multicolumn{2}{|c|}{$m g$} & \multicolumn{2}{|c|}{$m g$} \\
\hline Human $\dagger$ & 40 & 0 & 0.447 & 0.068 & 0.015 \\
\hline Rat & $\begin{array}{l}40 \\
40 \\
40 \\
40\end{array}$ & $\begin{array}{l}0 \\
0 \\
0 \\
0\end{array}$ & $\begin{array}{l}0.248 \\
0.211 \\
0.162 \\
0.224\end{array}$ & $\begin{array}{l}0.039 \\
0.030 \\
0.021 \\
0.027\end{array}$ & $\begin{array}{l}0.013 \\
0.017 \\
0.016 \\
0.009\end{array}$ \\
\hline $\begin{array}{l}\text { Dog } \\
\text { Mouse } \\
\text { Guinea pig } \\
\text { Cat }\end{array}$ & $\begin{array}{r}100 \\
40 \\
40 \\
200\end{array}$ & $\begin{array}{l}0 \\
0 \\
0 \\
0\end{array}$ & $\begin{array}{l}0.069 \\
0.158 \\
0.149 \\
0.053\end{array}$ & $\begin{array}{l}0.007 \\
0.015 \\
0.017\end{array}$ & $\begin{array}{l}0.013 \\
0.016 \\
0.012\end{array}$ \\
\hline
\end{tabular}

* Incubation mixture consisted of $1 \mathrm{ml}$ of diluted liver homogenate contained in $0.1 \mathrm{M}$ phosphate buffer, $\mathrm{pH} 7.8$; $0.75 \mathrm{mg}$ BSP in $0.2 \mathrm{ml}$ phosphate buffer; and peptide or amino acid in $0.1 \mathrm{ml}$ phosphate buffer. Tubes were incubated for 15 minutes at $37^{\circ} \mathrm{C}$.

$\dagger$ Liver biopsy obtained at laparotomy for cholelithiasis. 
The quantity of BSP conjugated by liver homogenate upon incubation with several peptides and amino acids was examined. Human, rat, dog, mouse, guinea pig and cat liver homogenates diluted with phosphate buffer did not form conjugate with BSP (Table II). BSP conjugates were formed, however, when glutathione, cysteinyl glycine or cysteine was added to the incubation mixture. Much more conjugate was formed per unit time with glutathione than with equimolar quantities of cysteinyl glycine or cysteine. No conjugate was formed with oxidized glutathione, cystine, taurine, methionine, glycine, glutamic acid or alanine.

Chromatographs of the BSP compounds synthesized by a 40 to 60 per cent ammonium sulfate

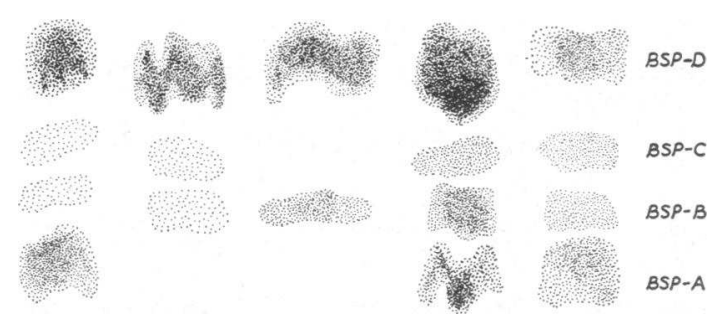

\begin{tabular}{|c|c|c|c|c|}
\hline $\begin{array}{c}\text { BSPP } \\
\text { Glutathione } \\
\text { (GSH) }\end{array}$ & $\begin{array}{c}\text { BSP } \\
\text { CysteinyI } \\
\text { Glycine } \\
\text { LCG) }\end{array}$ & $\begin{array}{c}\text { BSP } \\
\text { Cysteine } \\
\text { (CYS) }\end{array}$ & $\begin{array}{c}\text { BSP } \\
G S H_{+}^{+} C G \\
C \dot{+}=\end{array}$ & $\begin{array}{l}\text { BSP } \\
\text { BILE }\end{array}$ \\
\hline
\end{tabular}

Fig. 5. Drawing of chromatograms of BSP comPOUNDS IDENTIFIED IN INCUBATION MIXTURES CONTAINING LIVER ENZYME, BSP AND VARIOUS PEPTIDES AND AMINO ACIDS. The liver enzyme was a 40 to 60 per cent $\left(\mathrm{NH}_{4}\right)_{2} \mathrm{SO}_{4}$ fraction of the soluble supernatant fraction of the liver. BSP and glutathione yielded four bands. BSP-A and BSP-D were prominent. Only traces of $\mathrm{BSP}-\mathrm{B}$ and BSP-C were identified. BSP and cysteinyl glycine yielded three bands, BSP-B, BSP-C and BSP-D. BSP and cysteine yielded only BSP-B and BSP-D. Mixing the contents of tubes originally containing BSP and glutathione, BSP and cysteinyl glycine, and BSP and cysteine yielded a chromatogram resembling that of bile containing excreted BSP very closely.
TABLE III

Bromide released during glutathione conjugation

\begin{tabular}{|c|c|c|c|c|}
\hline Compound & Enzyme* & $\begin{array}{l}\text { Gluta- } \\
\text { thione }\end{array}$ & $\begin{array}{l}\text { Cpd. } \\
\text { conju- } \\
\text { gated }\end{array}$ & $\begin{array}{c}\text { Moles } \\
\text { bromide } \\
\text { released } \\
\text { mole } \\
\text { conju- } \\
\text { gated } \dagger\end{array}$ \\
\hline & \multirow[t]{2}{*}{$m l$} & $m g$ & \multirow{2}{*}{$\underset{m i n}{m g / 30}$} & \\
\hline BSP & & & & \\
\hline $\begin{array}{l}2 \\
2\end{array}$ & 1 & $\begin{array}{l}4 \\
4\end{array}$ & $\begin{array}{l}0.15 \\
1.61\end{array}$ & $\begin{array}{l}1 \\
1\end{array}$ \\
\hline 2 & \multirow{2}{*}{ 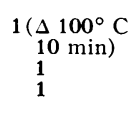 } & 4 & 0.06 & 1 \\
\hline 2 & & 4 & $\begin{array}{l}\mathbf{0} \\
0\end{array}$ & $\begin{array}{l}0 \\
0\end{array}$ \\
\hline $\begin{array}{c}\text { PTBP } \ddagger \\
1.5\end{array}$ & 1 & 4 & 0.17 & 1 \\
\hline PP\& & & & & \\
\hline 0.75 & 1 & 4 & 0 & 0 \\
\hline
\end{tabular}

* 40 to 60 per cent $\left(\mathrm{NH}_{4}\right)_{2} \mathrm{SO}_{4}$ fraccion of liver supernatant fraction. $\dagger$ The figure 1 is an approximation of actual ratio which could have varied between 0.75 and 1.25 because of possible errors in quantitating bromide (see Methods)

$\ddagger$ Phenoltetrabromphthalein dissolved in $0.8 \mathrm{ml}$ of $66.7 \%$ ethyl alco-

\$ Phenolphthalein dissolved in $0.8 \mathrm{ml}$ of 66.7 per cent ethyl alcohol.

fraction of the soluble supernatant fraction of rat liver were sprayed with alcoholic $\mathrm{KOH}$ (1 part $2 \mathrm{~N} \mathrm{KOH}$ and 19 parts absolute ethanol). The BSP bands were identified by their purple color and, when examined with ultraviolet light, by their red fluorescence. Although BSP bands corresponding only to BSP-A and BSP-D were seen in room light, four BSP bands were identified in the mixture containing glutathione by means of ultraviolet light. Three bands were identified when BSP was incubated with cysteinyl glycine. Only two bands were seen with cysteine (Figure 5). For comparison, a chromatogram of BSP compounds excreted in the bile of a rat after BSP was administered intravenously is shown. Four $\mathrm{BSP}$ bands are identified. BSP-A, B and C represent BSP conjugates, whereas BSP-D is free BSP. It is apparent that the bands in the glutathione mixture conform to the bands in BSP bile. Band $A$ is the most prominent conjugate. Only traces of $\mathrm{B}$ and $\mathrm{C}$ can be seen. Cysteinyl glycine and BSP yielded bands corresponding to BSP conjugates $B$ and $C$ (12). In the cysteine mixture, only one conjugate was seen and this conformed to BSP-B. A mixture of the compounds synthesized from glutathione, cysteinyl glycine and cysteine yielded a chromatograph resembling BSP bile very closely.

Inorganic bromide was released during conjugation of BSP and glutathione (Table III). In- 
TABLE IV

$B S P$-conjugating activity of various organs

\begin{tabular}{lc}
\hline \multicolumn{1}{c}{ Tissue } & BSP conjugated \\
\hline & $\mathrm{mg} / \mathrm{g}$ wet \\
wt $/ 5 \mathrm{~min}$ \\
Liver & 2.300 \\
Kidney & 0.108 \\
& 0.058 \\
Spleen & 0.153 \\
Intestine & 0.015 \\
Lung & 0.058 \\
Brain & 0.230 \\
& 0.147 \\
Skeletal muscle* & 0.010 \\
Red blood cells & 0
\end{tabular}

* Difficult to homogenize.

cubation of $2 \mathrm{mg}$ of BSP with $4 \mathrm{mg}$ of glutathione for 30 minutes yielded $0.15 \mathrm{mg}$ of conjugated BSP. When enzyme was added to the incubation mixture, $1.61 \mathrm{mg}$ of $\mathrm{BSP}$ was conjugated. Enzyme activity was destroyed by heating at $100^{\circ} \mathrm{C}$ for 10 minutes. No conjugate was formed when either BSP or glutathione was omitted from the incubation mixture. In the studies in which BSP conjugation occurred, approximately 1 mole of bromide ion was released for each mole of conjugate formed. Free bromide ion was not detected in the absence of conjugate formation, suggesting that bromide release is intimately related to BSP conjugation. This was supported by results obtained upon incubation of compounds related to $\mathrm{BSP}$ with enzyme and glutathione. When phenoltetrabromphthalein (PTBP, BSP minus the 2 sulfonic acid groups), a halogen-containing compound, was the substrate, a small amount of conjugate was formed with release of approximately 1 mole of bromide for each mole of conjugate formed. Phenolphthalein (PP, BSP minus the 2 sulfonic acid groups and 4 bromine atoms), a halogenfree compound, did not form a glutathione conjugate.

The distribution of enzyme activity in various tissues of the rat other than liver was examined. Small amounts of enzyme activity were found in most tissues (Table IV). None was detectable in red blood cells.

\section{DISCUSSION}

A liver enzyme that catalyzes the conjugation of BSP with glutathione has been demonstrated in the present studies. Although a small quan- tity of BSP-glutathione conjugate is formed per unit time when BSP and glutathione are incubated in vitro, the rate of conjugation is enhanced considerably upon addition of liver homogenate to the incubation mixture. As expected in reactions catalyzed enzymatically, the rate of BSP conjugate formation is proportional to the amount of liver homogenate added to the incubation mixture, and thus presumably to enzyme concentration. Furthermore, enzyme activity is destroyed by heating liver homogenate at $100^{\circ} \mathrm{C}$.

Glutathione is the optimal substrate for conjugation with BSP in the enzyme-catalyzed reaction in vitro. Cysteine and cysteinyl glycine also combine with BSP, but the rate at which these compounds form BSP conjugates is much slower than with glutathione. These observations support previous conclusions that conjugation of BSP with glutathione is the major pathway of BSP metabolism in vivo $(5,6)$. A free sulfhydryl group appears to be necessary for conjugation, since oxidized glutathione, cystine and methionine do not form BSP conjugates. BSP conjugation also did not occur with glycine, glutamic acid and alanine -amino acids identified after acid hydrolysis of BSP conjugates (2-6) -a finding which further supports the conclusion that it is glutathione that is conjugated with BSP. It is of interest that most of the glutathione in liver is contained in the soluble supernatant fraction (13). All of the BSPconjugating enzyme activity is also found in this compartment of liver cells. Such localization of enzyme and substrate is optimal for BSP-glutathione conjugation.

The release of approximately 1 mole of bromide ion from BSP for each mole of BSP-glutathione conjugate formed was regularly observed in both the uncatalyzed and enzyme-catalyzed reactions in the present studies. The release of inorganic bromide during the uncatalyzed reaction has also been reported recently by Javitt and his associates (6). These observations are at variance with the findings of Krebs and Brauer (1), which indicated that the ratio of bromine to sulfur in the major BSP metabolite in rat bile was the same as that of standard BSP, namely 4 bromine to 2 sulfur atoms. Since the major BSP conjugate in rat bile, BSP-A, appears to be composed of 1 mole of BSP conjugated with 1 mole of glutathione (5), one would expect this compound to 
have a ratio of 3 bromine to 3 sulfur atoms. A similar ratio of bromine to sulfur, $3: 3$, should also exist in the other BSP metabolites found in rat bile, BSP-B and BSP-C. Javitt and coworkers have also reported the presence of a BSP-diglutathione compound after incubation of $\mathrm{BSP}$ and glutathione in vitro, and have suggested that this compound appears occasionally in small quantities in rat bile (6). Although we have never identified such a compound in rat bile, it would be expected to have a bromine to sulfur ratio of $2: 4$.

Several observations indicate that bromide release is intimately related to BSP conjugation with glutathione. Bromide is released whenever BSP-glutathione is formed, whether the reaction is enzyme-catalyzed or not. It is not released in the absence of conjugate formation. Phenoltetrabromphthalein, a bromine-containing compound closely related structurally to BSP, forms a glutathione conjugate with release of inorganic bromide. However, phenolphthalein, a halogen-free compound, does not form a glutathione conjugate. Conjugation of BSP with glutathione appears to be dependent, therefore, on the presence of its halogen groups. Previous studies indicated that glutathione was conjugated with BSP in thioether linkage $(5,6)$. The available sites for conjugation on the BSP molecule included the free positions on the phenolic groups and the positions occupied by the 4 bromine atoms. The present data suggest that the sulfur group of glutathione attaches to BSP at the site of bromine removal. The observations that inorganic bromide is released from BSP upon incubation of BSP and glutathione in the absence of enzyme, and that no bromide is released when BSP is incubated with enzyme in the absence of glutathione, suggest that a function of the enzyme is to enhance the reactivity of the sulfhydryl group of glutathione.

In a previous publication (5), it was concluded that BSP-A, the major BSP compound in rat bile, is a conjugate of $\mathrm{BSP}$ and glutathione. $\mathrm{BSP}$ and BSP-C, minor BSP bands, were felt to contain isomers of BSP-glutathione as well as mixtures of its hydrolytic products, such as BSP-cysteinyl glycine and BSP-cysteine. These conclusions are supported by the current studies in which BSP compounds were formed enzymatically in vitro. Isomers of BSP-glutathione would be explained by conjugation of glutathione at different sites of bromine removal.

BSP-conjugating enzyme has been identified in the livers of many species. It has also been found to a lesser extent in many other organs. These latter findings are consistent with the observations of Rosenau, Carbone and Grodsky, indicating that BSP metabolites may appear in blood of hepatectomized animals (14).

The precise role of BSP conjugation in the movement of BSP from blood to bile is as yet unknown. Although it is recognized that other factors, such as hepatic blood flow and protein binding of BSP in plasma, may play a role in the hepatic uptake of BSP, the demonstration that BSP metabolism depends on glutathione and a liver enzyme suggests that the impaired removal of BSP from blood, in liver disease, may be related also to either alterations in hepatic glutathione content or conjugating enzyme activity, or both.

\section{SUMMARY}

An enzyme that catalyzes the conjugation of BSP and glutathione has been identified in the soluble supernatant fraction of liver. Glutathione is the optimal substrate. No requirement for cofactor has been demonstrated. Inorganic bromide is released from BSP during conjugation. The sulfhydryl group of glutathione appears to conjugate with BSP at the site of bromine removal.

\section{ACKNOWLEDGMENT}

The authors are indebted to Mrs. Ruthie Rose and to Mr. Allen White for valuable technical assistance.

\section{REFERENCES}

1. Krebs, J. S., and Brauer, R. W. Metabolism of sulfobromophthalein sodium (BSP) in the rat. Amer. J. Physiol. 1958, 194, 37.

2. Combes, B. The biliary excretion of sulfobromophthalein sodium (BSP) in the rat as a conjugate of glycine and glutamic acid. J. clin. Invest. 1959, 38, 1426.

3. Meltzer, J. I., Wheeler, H. O., and Cranston, W. I. Metabolism of sulfobromophthalein sodium (BSP) in dog and man. Proc. Soc. exp. Biol. (N. Y.) 1959, 100, 174.

4. Grodsky, G. M., Carbone, J. V., and Fanska, R. Identification of metabolites of sulfobromophthalein. J. clin. Invest. 1959, 38, 1981.

5. Combes, B., and Stakelum, G. S. Conjugation of sulfobromophthalein sodium with glutathione in 
thioether linkage by the rat. J. clin. Invest. 1960, 39, 1214.

6. Javitt, N. B., Wheeler, H. O., Baker, K. J., Ramos, O. L., and Bradley, S. E. The intrahepatic conjugation of sulfobromophthalein and glutathione in the dog. J. clin. Invest. 1960, 39, 1570.

7. Dounce, A. L., Witter, R. F., Monty, K. J., Pate, S., and Cottone, M. A. A method for isolating intact mitochondria and nuclei from the same homogenate, and the influence of mitcchondrial destruction on the properties of cell nuclei. J. biophys. biochem. Cytol. 1955, 1, 139.

8. Pollard, F. H., and McOmie, J. F. W. Chromatographic Methods of Inorganic Analysis, With Special Reference to Paper Chromatography. New York, Academic Press, 1953.

9. Mitchell, L. C. Separation and identification of acids by paper chromatography. I. The halides. J. Ass. off. agr. Chem. 1955, 38, 832.
10. Dent, C. E. A study of the behaviour of some sixty amino-acids and other ninhydrin-reacting substances on phenol-"collidine" filter-paper chromatograms, with notes as to the occurrence of some of them in biological fluids. Biochem. J. 1949, 43, 169.

11. Datta, S. P., Dent, C. E., and Harris, H. An apparatus for the simultaneous production of many two-dimensional paper chromatograms. Science 1950, 112, 621.

12. Gutcho, M., and Laufer, L. Paper chromatography of glutathione and its hydrolysis products in Glutathione. New York, Academic Press, 1954, p. 79.

13. Edwards, S., and Westerfeld, W. W. Blood and liver glutathione during protein deprivation. Proc. Soc. exp. Biol. (N. Y.) 1952, 79, 57.

14. Rosenau, W., Carbone, J. V., and Grodsky, G. M. Metabolism of sulfobromophthalein in hepatectomized and hepatectomized-nephrectomized dog. Proc. Soc. exp. Biol. (N. Y.) 1959, 102, 131. 